\title{
FARMERS ADAPTATION STRATEGIES TO THE EFFECT OF CLIMATE VARIATION ON YAM PRODUCTION: A CASE STUDY IN EKITI STATE, NIGERIA
}

\author{
Oluwasusi, J. $0 .{ }^{1}$ and Tijani, S.A. ${ }^{2}$ \\ Department of Agricultural Extension and rural development \\ University of Ibadan, Ibadan \\ Corresponding Author: yesky20@yahoo.com; Telephone: +2348032094612
}

\begin{abstract}
The study investigated farmers adaptation strategies to the effect of climate variation on yam production in Ekiti State with the specific objectives of assessing the socio-economic characteristics of farmers, farmers' climate related constraints, the adaptation strategies employed by farmers, and yam farmers' level of production across the years 2008, 2009 and 2010. A three - stage multistage sampling technique was used to select one hundred and fifty one respondents from the list of contact farmers obtained from the state Agricultural Development Programme (ADP). Data collected through questionnaire were analysed using frequency counts, percentages, Chi-square, Pearson Product Moment Correlation and ANOVA. Results obtained showed that farmers in the study area were mostly males with a mean age of 53.9 years. Chisquare analysis revealed that there was a significant relationship between secondary occupation $\left(X^{2}=14.068\right)$, farm size $\left(X^{2}=99.597\right)$ and the level of production of yam farmers. Pearson product moment correlation indicated that there were significant and positive relationships between age ( $r$ $=0.160)$, adaptation strategies $(r=0.158)$ and level of production, while negative relationship was found between constraints $(r=-0.173)$ and the level of yam production. ANOVA showed a significant difference in the level of production of farmers across the years; 2008, 2009 and 2010 $(F=212.7)$. Therefore, efforts should be geared towards developing and making available, yam setts that are tolerant to change in climate elements and weather extremes like flood and drought. This study also suggests the need for prompt weather information, increased research and development of innovation for sustainable yam cropping in the face of climate variation.
\end{abstract}

Key words: Climate variation, Constraints, Adaptation

\section{INTRODUCTION}

Agriculture is a climate dependent activity that places serious burden on the environment in the process of providing the teaming Nigeria population with food and fibres. The effect of climate on agriculture is related to variability in local climates rather than in global climate patterns (Fraser, 2008). Climatic variation is the mean state of climate on all temporal and spatial scales of weather events (Adger, 2003). Climate change is often used synonymous with climate variability and yet the two are different. Climate change refers to the long-term significant change in the "average weather" that a given region experiences, while climate variation refers to variation in the mean state and other statistics of climate on all temporal and spatial scales beyond that of individual weather events (IPCC, 2007). Climate change is a significant and lasting change in the statistical distribution of weather patterns over periods spanning from decades to millions of 
years, while climate variation is a short term fluctuation in weather patterns spanning from years to decades.

Climate variability is the resultant effect in the alterations of ecosystem structures to satisfy human land use and livelihood potentials of the human race. Effects of climate variation are physical, economic, social and cultural, endangering environmentally based livelihoods of the Nigeria population. Climate variability have direct impacts that causes vulnerability to the natural and social systems through changes in average temperatures, temperature extremes and extreme weather events like flooding and droughts.

Adger et.al, (2007) posited that climate variability, poor infrastructure, economic poverty, drought, excess rainfall, poor livestock health, reduced crop yields, low productivity and a range of other problems associated with climate variability will constitute important challenges for Africa Countries in particular. The effect of climate variation is being felt by the whole population but, it will disproportionately affect vulnerable groups and vulnerable population (Lobell et.al, 2008a). Africa's population in which Nigeria is a key player in terms of population size and market for agricultural produce domestically is very vulnerable to climatic and non-climatic changes, due to high level of poverty, conflicts and prevalence of diseases. Changes in climate are severely affecting agricultural production in many African countries (UNEP, 2007). Increased temperatures and accompanying decrease in water availability reduce the length of growing seasons and yield potential and hence the areas suitable for agriculture, further adversely affecting food security over the continent (Thornton, et al., 2006).

Yam is the foremost staple food to the people of Ekiti state, appreciated from its taste and significant cultural role as a major menu when pounded in ceremonial occasions. Ekiti state is a major contact centre for yam marketing in south western Nigeria (Awoniyi and Omonona, 2006). Yam farming is a major source of livelihood and food security to the Ekiti people. Yam is highly revered among the people but its cultivation is declining steadily, may be as a result of high incidence of field diseases, pest attack and high post harvest losses as a result of changing climate, yet the crop enjoys ready market demand in the state. However, as yam production is changing, the Ekiti man is changing in reaction to pressures from socio-economic and environmental pressures (Omojola, 2006).

The unstable conditions of farming can thus, affect the overall productivity of farmers, make them abandon farming for some time, produce at capacities below their best or have little gains for their efforts. Climate variation already poses significant impacts on the agricultural sector and there has been little commitment to make adaptation a national priority in the country. The draw back in adaptation is attributed to low and poor scientific development as most development innovations are not built on indigenous knowledge of farmers, to provide for sustainability of new practices. The associated impacts of climate variation are predominantly negative, with the most severe impacts being experienced in vulnerable communities that accommodate the bulk of Nigerian farmers, practicing farming at subsistence levels with very weak capacity to adapt. Yam production and yield patterns are of economic importance to the livelihood of an average Ekiti farmer, as they have link with income generation and economic sustainability in rural communities in the state. 
Adaptation is the adjustment in natural or human systems in response to actual or expected climate stimuli or their effects, which moderated harm or exploits beneficial opportunities (UNFCCC, 2007). The yam farmers, to a large extent have been able to develop their livelihood strategies in a way that enables them to constantly cope and adapt to the changing climatic conditions, pest attack and agricultural policies in the country. Farmers' ability to adapt to impacts of climate variation depends on factors such as wealth, technology, education, information, infrastructure, access to resources and management abilities. There is need to gain as much information as possible and learn the positions of the rural farmers and their needs about what they know about climate variation and change in order to offer adaptation practices that meet their needs (Lobell et.al, 2008b). Providing answer to the above question necessitated this study, hence the specific objectives of this study therefore, are to describe the (i) socio-economic characteristics of the respondents, (ii) identify climate constraints on yam production, (iii) ascertain adaptation strategies adopted to mitigate effect of climate variation and (iv) assess the level of production of yam farmers.

The hypotheses were stated in the null form $(\mathrm{Ho})$ were tested

Ho1: There is no significant relationship between the socio-economic characteristics of the farmers and their level of yam production,

Ho 2: There is no significant relationship between the constraints faced by the respondents and their level of yam production,

Ho 3: There is no significant relationship between the respondents' adaptation strategies to climate variation and their level of yam production,

Ho 4: There is no significant difference in the level of production of the respondents in the years 2008, 2009 and 2010

The hypothesis was rejected if the $P$-value was $\leq a=0.05$.

\section{RESEARCH METHODOLOGY}

The study was conducted in Ekiti state, Nigeria in 2011. The choice of Ekiti state for this research was due to its prevalent yam production in South Western Nigeria. Ekiti state is located between latitudes $7^{\circ} 25^{\prime}$ and $80^{\circ} 5^{\prime}$ East of Greenwich Meridian and between longitude 40 45' and 46 $5^{\prime}$ North of the Equator. The state is bounded to the North by Kwara and Kogi states while it is bounded by Osun state to the West, Edo to the East, and Ondo to the South. Ekiti state is a landlocked state, having no coastal boundary. The Ekiti people are culturally homogenous and speak a dialect of the Yoruba language known as Ekiti. In terms of arts and culture, Ekiti State is among the richest in the federation in the variety and quality of its tradition, arts, music and poetry. The Ekiti people are good wood carvers, blacksmith, and ornamental potters, mat weavers and basket makers. The main occupation of Ekiti people is farming. Hence, the State is agrarian in nature and therefore has many rural settlements. The state enjoys a tropical climate with two distinct seasons: rainy season (April to October) and dry season (November to March). The temperature ranges from $21^{\circ} \mathrm{C}$ to $28^{\circ} \mathrm{C}$, with high humidity. The population of the inhabitants of the state, according to a 2006 population census, was 2,737,186 (NPC, 2006). Their major 
agricultural produce includes cocoa, kolanut, orange (and other citrus), oil palm, maize, rice, cassava, yam, sweet potato and melon.

\section{Sampling procedure}

The population involved in this study consisted of yam farmers in Ekiti state. Ekiti state was purposively selected for this study because of its prevalent yam farming practice. A three-stage multi-stage sampling technique was used for this study. The first stage involved the random selection of two ADP zones from the three ADP zones of Aramoko, lkole and lkere in the state (Aramoko and lkere zones). The second stage involved random selection of two blocks from each zone having at least eight cells in each block. Twenty five percent of the cells from each zone was randomly selected, the selected cells from Aramoko zone were; Ara, lloro, Iwaji and Ita Ore while Afao-Kajola, Ogbonjana, Eporo and Aba Itire were selected from Ikere zone. In the third stage, the lists of registered farmers in the selected cells were obtained from the block extension agents in Ekiti State ADP and snow ball technique was also used to locate some unregistered farmers. Nineteen farmers were selected from each cell to make a total of 152 respondents which constituted the sample size for the study. However, only one hundred and fifty one (151) questionnaires were analyzable giving a response rate of $99 \%$. This research work was conducted between August 2010 and August 2011 and data was collected between February 2011 and April 2011.

\section{Data collection and analysis}

Data were collected from the primary sources (respondents) with the aid of a structured questionnaire. The data collected were analysed with the aid of the descriptive statistics of frequency counts and percentages. Inferential statistics such as, Chi-square $\left(X^{2}\right)$, Pearson Product Moment Correlation and Analysis of Variance (ANOVA) were used to analyse the study hypotheses. The climate related constraints encountered by the respondents in yam production was measured on a three point scale of serious $=1$, mild $=2$ and not a constraint $=0$ while adaptation strategies employed by respondents to mitigate the effect of climate variation on yam production was measured on a three point scale of sometimes $=1$, most times $=2$ and all the time $=3$. The level of yam production was measured through calculation of the four types of yam planted in Ekiti state; white yam, yellow yam, water yam and bitter yam graded into big, medium and small categories across the years of 2008, 2009 and 2010 using the recall and business record methods by the respondents to know the effect of climate variation on the yam produced. These were later converted to tonnes $(1000 \mathrm{Kg}=1$ tonne). Quantity of yam produced per hectare $X$ average weight $(\mathrm{kg}) / 1000$. The mean score of the respondents on level of production was obtained as 16 tonnes, while a maximum tonne of 122.9 and a minimum tonne of 7.61 tonnes of yam tubers were obtained as the respondents' tonnes of yam produce. Therefore, respondents with tonnes below 16 were categorised as having low production, while those with tonnes of 16 and above, have high level of production in the study area. 


\section{RESULTS AND DISCUSSION}

\section{Socio-Economic Characteristics}

Table 1, reveals that majority (89.4\%) of the respondents were between the ages of 41 and 70 years, with the mean age of 53.9 years; youth comprised only $10.6 \%$. This result shows that most of the farmers in the study area old while young people prefer less climate risk business. The majority of the respondents (87.4\%) were male, suggesting that yam farming is more practiced by males as a result of the drudgery and strenuous agronomic practices involved in its production. The results further show that the majority (97.4\%) of the farmers were married, while very few were widowed. This means that married people were more involved in yam farming and may receive assistance from their spouses in carrying out some activities on the farm. In terms of education, more than half $(53 \%)$ of the respondents had a form of formal education: primary, secondary or post-secondary education. Almost $47 \%$ had no formal education. This implies that majority of the respondents were literates, which is in support of Williams (1997) that reported that farmers' adoption of improved technology is influenced by their level of education, thus respondents' level of education will assist them to seek information on climate variation.

The farming experience of the respondents' shows that, majority of the respondents (88.7\%) had been cultivating yam for more than 20 years, while only $11.3 \%$ had been cultivating yam for a period less than 20 years. This implies that the respondents had useful information and experiences of variation in climate with coping mechanisms as it affects their farming practices and production. Also, the Table 1 further shows that more than half $(58.9 \%)$ of the yam farmers had between 1 to 3 hectares of yam farm land, about $4 \%$ of the farmers had more than 7 hectares of yam plot while those that had between 4 to 6 hectares accounted for $37.1 \%$. The result shows that many of the respondents were small scale farmers and that farm size is a critical factor influencing the output of farmers. This is in consonance with similar result obtained by Olayide (1990) who categorized small scale farmers as ranging from 0.2 hectares to 9 hectares holding in Nigeria. Thus, the respondents in this study area have farm sizes of less than 9 hectares justifying the respondents' as small scale farmers. 
Oluwasusi \& Tijani, 2013

Table 1: Distribution of respondents by Socio-economic characteristics

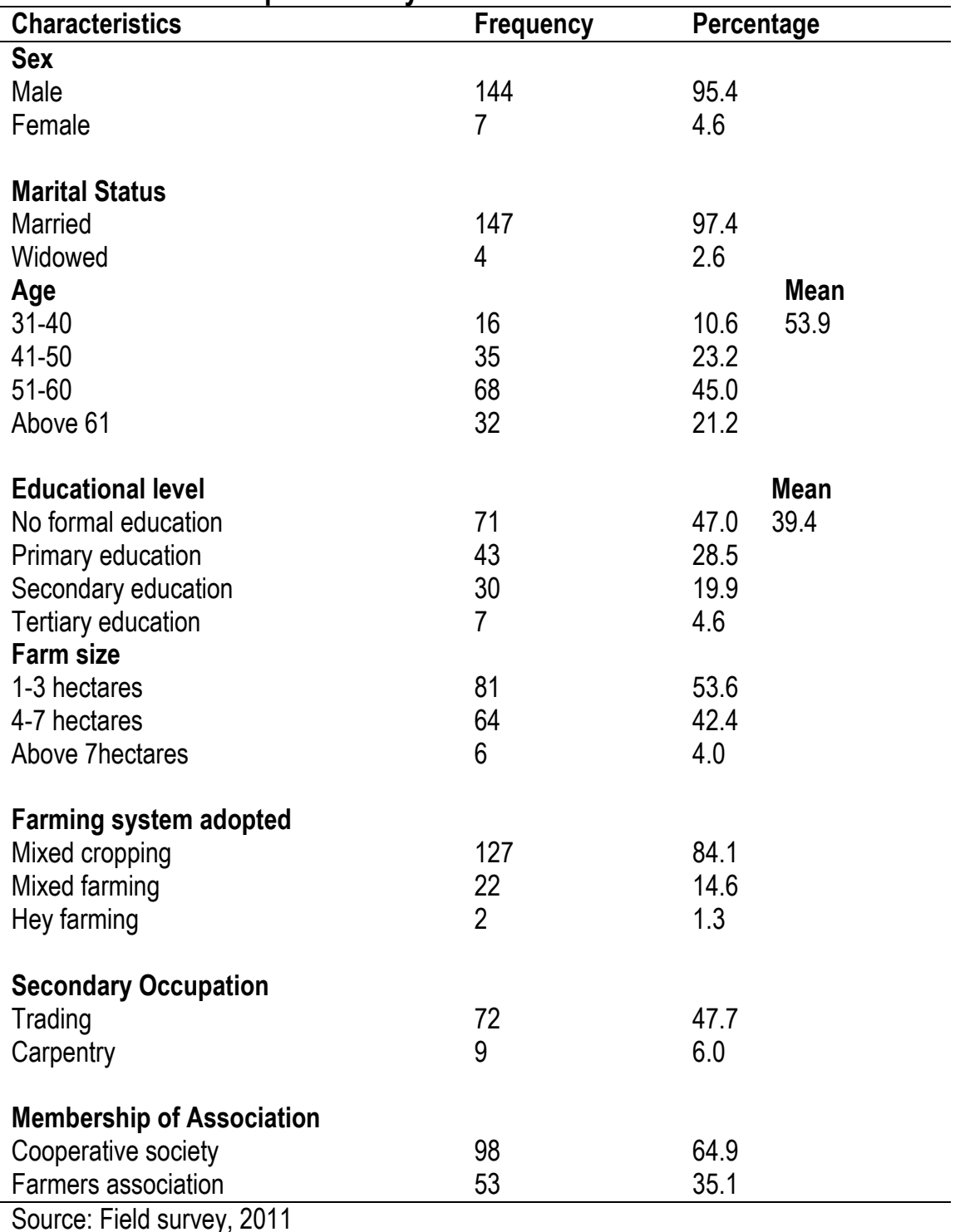

Source: Field survey, 2011

Majority (84.1\%) of the respondents practiced mixed cropping, $14.6 \%$ practiced mixed farming, while $1.3 \%$ practiced hey farming. It implies that the respondents practiced mixed cropping to guarantee all-year-round production to insure the farmers against total crop failure. Large percent $(64.9 \%)$ of the respondents belonged to one cooperative society or the other, while $35.1 \%$ belonged to farmers' association. The respondents were primarily into farming while $(47.7 \%)$ were into trading as secondary occupation. This indicates that a large number of the farmers engage in other livelihood diversification means to meet their demanding family and social responsibilities. 
The description of the distribution of yam farmers on climate related constraints encountered in yam production is presented in Table 2

Table 2: Distribution of yam farmers on climate related constraints encountered in yam Production $(n=151)$

\begin{tabular}{llll}
\hline \multicolumn{1}{c}{ Constraints } & \multicolumn{3}{c}{ Effect of Constraint } \\
& Serious & Mild & Not a Constraint \\
\hline Reduction of soil fertility & 99.3 & 0.7 & 0 \\
Instability in planting calendar & 99.3 & 0 & 0.7 \\
Drying of yam seed after germination due to high temperature & 89.4 & 7.3 & 3.3 \\
Lack of timely information on weather conditions & 91.0 & 6.0 & 3.0 \\
Deteriorating road state from farm gates to market centres & 83.4 & 8.6 & 8.0 \\
Shortage of water & 99.3 & 0.7 & 0.0 \\
Stunted growth & 87.4 & 4.6 & 8.0 \\
Erosion occurrence and wind storm & 93.4 & 5.3 & 1.3 \\
Withdrawal of labour force to less climate risk ventures & 10.6 & 72.8 & 16.6 \\
Spread of pests and diseases & 98.0 & 0.7 & 1.3 \\
Low yield & 99.3 & 0.7 & 0 \\
Ineffectiveness of agricultural chemicals used due to delay in rainfall & 54.3 & 44.4 & 1.3 \\
\hline
\end{tabular}

Source: Field survey, 2011

Table 2 shows the various climate related constraints, the yam farmers faced in yam production in the state. Majority of the respondents (93.3\%) indicated reduction of soil fertility, instability of planting calendar, shortage of water, low yield, untimely weather forecast, erosion occurrence and wind storm as serious constraints confronting yam production. Other constraints recorded high percentage of seriousness except inadequate labour that recorded low level of seriousness $(10.6 \%)$. This means that majority of the yam farmers had access to labour which could help enhance their production capacity but limited by other factors. CBN (2005) validated this finding that in Ekiti state, $90 \%$ of the rural labour force is engaged in agriculture.

Table 3 shows the various adaptation strategies employed by yam farmers to mitigate the impact of climate variation. All the respondents (100\%) indicated planting of cover crops, mulching, planting of early maturing yam seed and movement to different site which are cultural practices, as adaptation strategies employed to mitigate the effect of climate variation. Other adaptation strategies recorded high percentage of usage except, use of weather forecast which is noncultural $(45.7 \%)$ that recorded low level of usage. This means that weather forecasts information is not readily accessible and available to the farmers. Ole et al (2009) validated the above findings that rural communities in Nigeria have always managed their resources and livelihoods in the face of challenging environmental and socio-economic conditions. 
Oluwasusi \& Tijani, 2013

Table 3: Distribution of respondents' adaptation strategies on climate variation

\begin{tabular}{llcccc}
\hline \multicolumn{1}{c}{ Adaptation Strategies } & \multicolumn{2}{c}{ Yes } & \multicolumn{4}{c}{ Frequency of use } \\
& Frequency & \% & SM & MT & AT \\
\hline Planting of cover crops & 151 & 100 & 10.6 & 25.82 & 63.58 \\
Mulching & 151 & 100 & 1.3 & 1.3 & 97.4 \\
Mixed farming & 151 & 100 & 1.3 & 17.9 & 80.8 \\
Movement to different site & 151 & 100 & 1.3 & 86.1 & 12.6 \\
Planting of early maturing yam seed & 151 & 100 & 58.9 & 41.1 & 0 \\
Crop rotation & 146 & 96.7 & 1.99 & 39.74 & 54.97 \\
Application of farm yard manure & 133 & 88.1 & 27.2 & 13.9 & 47 \\
Increased/ Reduced land size cultivated & 131 & 86.8 & 40.4 & 27.9 & 18.5 \\
Change in planting periods & 127 & 84.1 & 35.1 & 45.7 & 3.3 \\
Diversification into non-farm activities & 126 & 83.4 & 35.1 & 48.3 & 0 \\
Changes in harvesting dates & 109 & 72.2 & 47 & 19.2 & 6 \\
Planting of trees & 108 & 71.5 & 69.5 & 2 & 0 \\
Lengthened fallow & 82 & 54.3 & 21.2 & 22.5 & 10.6 \\
Minimum tillage & 74 & 49 & 22.5 & 26.5 & 0 \\
Use of weather forecasts & 69 & 45.7 & 25.2 & 18.5 & 2 \\
\hline
\end{tabular}

Source: Field survey, 2011 Note: SM = Sometimes MT = Most times AT = All times

Table 4: Yam farmers' level of production

\begin{tabular}{lllllll}
\hline Level of Production & Scores & Frequency & Percentage (\%) & Mean & Maximum Score & Minimum Score \\
\hline High & 16a\&Above & 66 & 43.7 & 16 & 122.9 & 7.61 \\
Low & $1-15.9$ & 85 & 56.3 & & & \\
\hline Source: Field survey, 2011 & & & & &
\end{tabular}

Source: Field survey, 2011

The result shows that more than half (56.3\%) of the respondents had low level of production with many of them producing below mean value of 16 , while $43.7 \%$ had high level of production. This further shows that the attributed change in climate by the yam farmers is a major cause of low yam production in the study area.

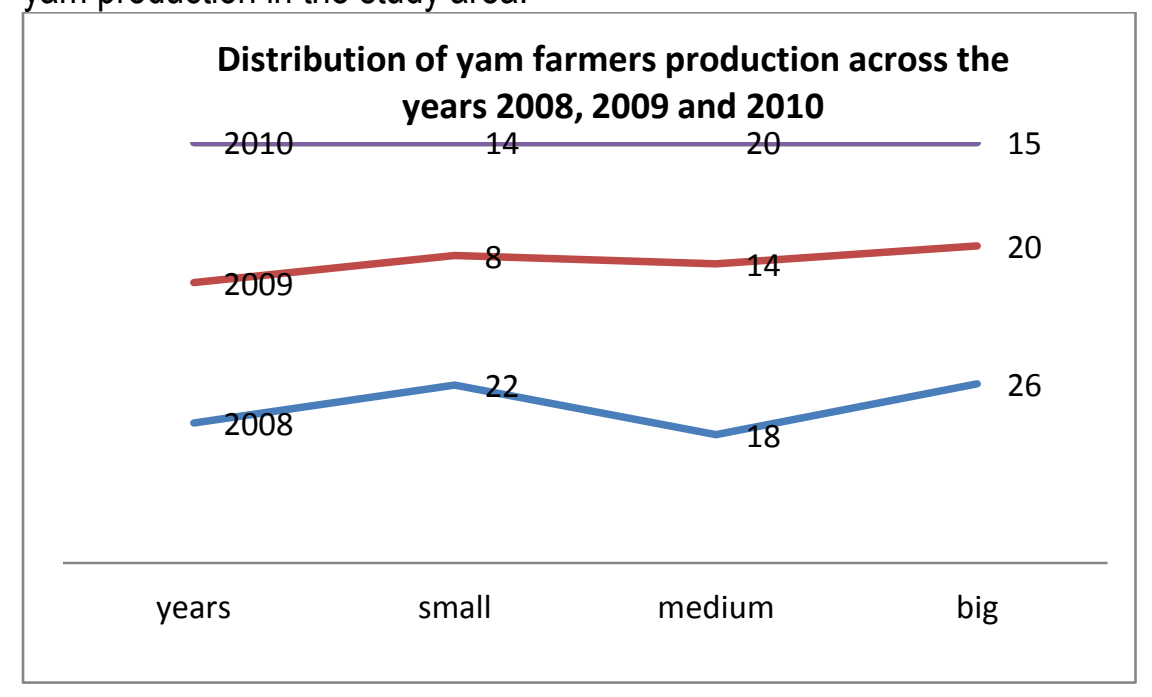


The distribution of yam farmers' production across the years of 2008, 2009 and 2010 showed a fluctuation, as more tonnes of yam are produced in 2008 than years 2009 and 2010 as a result of more stable climatic condition experienced in the year compared to other years.

\section{Test of hypotheses}

Chi-square analysis on Table 5 tested relationship between socio-economic characteristics of yam farmers and farmers' level of production.

TABLE 5: Chi-square result showing relationship between socio-economic characteristics of respondents and level of production

\begin{tabular}{|c|c|c|c|c|}
\hline Variable & Df & $X^{2}$ & Significant level & Decision on Significance \\
\hline Sex & 1 & 0.684 & 0.460 & Not Significant \\
\hline Marital Status & 1 & 0.585 & 0.445 & Not Significant \\
\hline Religion & 1 & 0.418 & 0.518 & Not Significant \\
\hline Level of education & 1 & 18.031 & 0.001 & Not Significant \\
\hline Membership of Association & 1 & 0.224 & 0.636 & Not Significant \\
\hline Farm Size & 2 & 99.597 & 0.000 & Significant \\
\hline Secondary Occupation & 1 & 14.068 & 0.001 & Significant \\
\hline Farming experience & 2 & 4.408 & 0.221 & Not Significant \\
\hline Type of farming system & 2 & 3.870 & 0.144 & Not Significant \\
\hline
\end{tabular}

Results shows that secondary occupation, farm size $\left(X^{2}=14.068\right.$ and $99.597 ; p<0.05$ respectively) of the respondents were statistically significant. The relationship between level of production and sex, marital status, level of education, religion, membership of association, farming experience and type of farming system $\left(X^{2}=0.469,0.445,0.168,0.518,0.636,0.221\right.$ and 0.144 respectively) of the respondents were not significant at $p<0.05$. These tests of relationships were carried out at nominal levels using chi-square. This implies that farmers with large farm sizes have higher economic resources part of which is land, and are better adopters of innovation on better yam farming, better producers of yam with more rewarding income than farmers with small farm sizes. Oluwatusin (2006) validated this finding that the importance of farm size cannot be over emphasized to farmers and the larger the farm size, the more the level of gross output level. Also, farmers with additional occupation and multiple streams of income are better yam producers. They know the intricacy of farming as a business with its own related risks, which increase as the scope of the farming gets bigger and are more market oriented than farmers who concede to yam farming as the only livelihood means to survival. Van den Ban (2002) corroborates this finding that only farmers who can manage to increase their productivity efficiently more than their competitors will be able to earn a living from farming.

TABLE 6: Pearson product moment correlation result showing correlation between age, adaptation strategies, climate related constraints and farmers level of production.

\begin{tabular}{llll}
\hline Variable & r-value & p-value & Decision on significance \\
Age & 0.160 & 0.049 & Significant \\
Adaptation strategies & 0.158 & 0.043 & Significant \\
Climate related constraints & -0.173 & 0.034 & Significant \\
\hline
\end{tabular}

${ }^{*}$ Correlation is significant at 0.05 
Pearson product moment correlation (PPMC) analysis was used to test the significant relationships of the identified independent variables with the level of production at interval levels on Table 6. These show that there were significant relationships between age $(r=0.160)$, adaptation strategies $(r=0.158)$, constraints faced by farmers $(r=-0.173)$ and farmers' level of production. This implies that as farmers increase in age they get more aware of climate variation, experienced and acquainted with constraints of yam farming, improved technology and are better adopters of improved technology which have a superior bearing with income generation and ultimately level of production than the young farmers in the study area.

Table 7: Comparing the level of production of respondents in the years 2008, 2009 and 2010

\begin{tabular}{lllll}
\hline Variable & & Df & F-value & p- value \\
\hline Yam production across & years & 148 & 212.7 & $0.005^{*}$ \\
$2008,2009,2010$ & & & & \\
\hline${ }^{*}$ Correlation is significant at 0.05 & & & &
\end{tabular}

Analysis of variance test (ANOVA) showed a significant difference in the level of production of farmers across the years; 2008, 2009 and 2010 ( $F=212.7 ; p<0.05)$. The result implies that, the level of production in the years 2008, 2009 and 2010 differ. It shows that their level of production over the years was decreasing as a result of climate variation. This could further be that, the limited resources available at the disposal of the farmers cannot sustain or increase their production in the wake of changing climatic conditions. These results agree with the finding of Adger et al (2007) that, it seems clear the combination of high climatic variability, poor infrastructure, economic poverty, drought, excess rainfall, poor livestock health, reduced crop yields, low productivity and a range of other problems associated with climate variability will constitute important challenges for Africa countries in particular. Thus, Ekiti state is not an exemption.

\section{CONCLUSION AND RECOMMENDATIONS}

The conclusion of the finding indicated that majority of the yam farmers had small farm sizes but well engaged in other livelihood activities to support farming. The farmers were aged with great experience in yam farming. The farmers were aware of climate variation and had enormous climate related constraints limiting their level of production. The farmers utilized both cultural soil conservation technologies and very few non-cultural technologies to mitigate the effect of climate variation but prefer cultural soil conservation technologies to non-cultural technologies which are less sustainable. Increased understanding of climate threats to agriculture in the state has not been met with a similarly improved understanding of how best to respond. If future climate moves quickly outside the range of the past and present experience, yam farmers may be unable to adapt rapidly enough without some help. The study therefore, establishes the fact that climate related constraints faced by yam farmers as a result of climate variation and adaptation strategies employed are important determinants of the level of production. 
Based on the findings of the study, the following recommendations are hereby suggested. Yam farming is a profitable, enterprising venture and an indispensable occupation to the people of Ekiti state and South west in general. A relative appropriate and sustainable yam farming practices should be encouraged among the farmers and the potential farmers. This could be achieved by government and non-governmental agencies ensuring the availability and accessibility of adaptable farming inputs to climate variation at subsidized rates and extend credit facilities to the farmers. Government should provide rural infrastructures and functional market system to rural communities in order to motivate yam farmers to stay in the enterprise. Policy makers should incorporate farmers' literacy programmes into extension services. This will avail the farmers the opportunity to understand non cultural soil technologies like strip cropping, compost, agro-forestry along with increase in the probability of adoption. Indigenous soil technologies should also be encouraged collaboratively with non-indigenous technologies to make it participatory and sustainable for the farmers.

Meteorological stations need to be resuscitated and well facilitated in terms of human, modern equipment and financial capitals to give accurate and prompt weather predictions for farmers' use. Local Government Areas (LGAs) should the locations of NIMET focal points.

Yam architecture and physiology may be genetically altered by agronomists to adapt to warmer environmental and drier conditions. The development of these new varieties with higher yield potential and stability will be complementary to bridging the yield gap.

\section{REFERENCES}

Adger, W. N.; Huq, S.; Brown, K.; Conway, D. and Hulme, M. (2003). "Adaptation to Climate Change in the Developing World" Progress in development studies 3(3):179-195.

Adger, W. N.; Agrawala S.; Mirza, M. M. Q; Conde, C.; O’Brien, K.; Pulhin, J.; Pulwarty, R.; Smit, B. and Takahashi, K. (2007): "Assessment of adaptation practices, options, constraints and capacity: Impacts, Adaptation and Vulnerability". Contribution of Working Group II to the Fourth Assessment Report of the Intergovernmental Panel on Climate Change, M.L. Parry, O.F. Canziani, J.P. Palutikof, P.J. van der Linden and Hanson, C. Eds., Cambridge University Press, Cambridge, UK, 717-743.

Akande, T. (2002). Making agriculture trade work for rural development. Elements for a developmentoriented agenda in the context of World trade organization negotiations. A presentation at the Joint ICTSD/FES roundtable on agriculture and sustainable development, Geneva, December, 2. $4 \mathrm{pp}$.

Awoniyi, O. A and Omonona B. T. (2006): Production efficiency in yam based enterprises in Ekiti State Nigeria. Central European Agriculture Journal 7 (4): 627-636.

Central Bank of Nigeria (CBN, 2005): Annual report and statement of accounts, 92-96.

Fraser, E. (2008). "Crop yield and Climate change" retrieved on Sept. 16, 2010 from $\mathrm{http} / \mathrm{www}$.fao/org/waicent/fao/agricult/gal/wrpur/Nigeria_bright.htm.

International Institute of Tropical Agriculture (2001): Annual report 2001. 24-30. 
Oluwasusi \& Tijani, 2013

IPCC (2007). Impacts, Adaptation, and Vulnerability. Contribution of Working Group II to the Third Assessment Report of the Intergovernmental Panel on Climate Change (Parry, Martin L, Canziani OF, Palutikof JP, van der Linden PJ, Hanson CE (eds.). Cambridge University Press, United Kingdom, 1000.

Lobell, D. B., Burke, M. B., Telbaldi, C., Manstranda, M. D., Fakon, W. P and Naylor, R. L (2008a): Priortizing Climate Change Adaptation Needs for Food Security in 2030. International Journal of Science 31(9) 60-71.

Lobell, D.B., Burke, M. B., Telbaldi, C., Manstranda, M. D., Fakon, W. P and Naylor, R. L (2008b): Priortizing Climate Change Adaptation Needs for Food Security in 2030. International Journal of Science 31(9) 60-71.

National Population Commission (2006). Population Figure, National Population Commission, Abuja, Nigeria.

Olayide, S. O. (1990). Characteristics Problems and Significance of Farmers. In Olayide S.O, Eweka, J.A and Bello Osagie, V.E (eds). Nigeria small farmers' problems and prospects in integrated rural development.

Ole, M. Cheikh, M. Anette, R. and Awa, D. (2009). Farmers' Perceptions of Climate change and Agricultural Strategies in Rural Sahel. Journal of Environmental Management 4(3) 804-816.

Oluwatusin, F. M. (2006). An Assessment of agricultural loan beneficiaries and non beneficiaries in Ekiti State Nigeria. Proceedings of the fifteenth annual congress of the Nigerian rural sociological association held at univesity of Ado-Ekiti, Ekiti state, Nigeria. $6^{\text {th }} 9^{\text {th }}$ November, 2006.

Thornton, P. K.; Jones, P. G.; Owiyo, T. M.; Krusta, R. L.; Herero, M. and Kristyanso, P. (2006). Mapping Climate Vulnerability and Poverty in Africa. Report to the Department for Inter-national Development. International Livestock Research Institute, Nairobi, 200p.

United Nations Environmental Programme (2007). Global Environmental Outlook. Environment for Development. Kenya: 540p.

United Nations Framework Convention on Climate Change (2007). Climatic Change Impact, Vulnerabilities and Adaptation in Developing Countries UNFCCC Secretariat, Martin-Luther-KingStreet 8, 53175 Bonn, Germany. Retrieved Feb.3, 2011 from htpp// www.unfccc.int.

Van den Ban. (2002). Increasing the ability of farmers to compete in the market. Journal of Extension. Verma O.S. 18 (2): 104.

Williams, S. K. T. (1997). Agricultural extension and food security in Nigeria. Proceedings of $3^{\text {rd }}$ annual national conference of AESON, March. 6, OAU. lle lfe. 